\title{
Effects of urine from females in oestrus on puberty in female mice
}

\author{
L. C. Drickamer \\ Biology Department, Williams College, Williamstown, MA 01267, U.S.A.
}

\begin{abstract}
Summary. A series of 9 experiments was conducted to examine various characteristics of the urinary chemosignal found in the urine of oestrous female mice that accelerates the sexual development of conspecific females. This urinary chemosignal was effective in doses as small as $0.001 \mathrm{ml} /$ day, was present in excreted and bladder urine, required 3 days of treatment starting before Day 29 of age to effect an acceleration of puberty, required a minimum daily exposure of $2 \mathrm{~h}$, and was relatively nonvolatile. In addition the chemosignal from oestrous females was effective in summer but not in winter months, was significantly more effective when collected at the middle or end of the dark portion of the daily cycle than at the beginning of the dark phase or middle of the light phase, and was not affected by food deprivation or shortened photoperiod. Simultaneous treatment of test subjects with urine from oestrous females and grouped females resulted in delays in puberty and simultaneous treatment with urine from oestrous females and urine from males or pregnant or lactating females did not result in any enhanced acceleration of puberty.
\end{abstract}

\section{Introduction}

There are at least 4 chemosignals in the urine of mice that influence the timing of puberty in females; urine from males, females in oestrus and females that are pregnant or lactating accelerates first vaginal oestrus (Vandenbergh, 1969; Colby \& Vandenbergh, 1974; Drickamer \& Murphy, 1978; Drickamer \& Hoover, 1979; Drickamer, 1982a), whereas urine from grouped females delays the onset of first oestrus (Vandenbergh, Drickamer \& Colby, 1972; Drickamer, 1974a). A great deal is known about the factors that influence the urine donors and female recipients for the chemosignals from males, grouped females and females that are pregnant or lactating (see reviews by Vandenbergh, 1983; Drickamer, 1986), but considerably less is known about the substance from the urine of females in oestrus.

The acceleratory effect on female puberty produced by the urine of females in oestrus was first reported by Drickamer (1982a). The urinary chemosignal from females in oestrus is influenced by density (Drickamer, 1982a) and the dominance status of the female (Drickamer, 1985), but there are no differential effects of this puberty-accelerating substance based upon the degree of relatedness between donor and recipient (Drickamer, 1984a). The acceleratory phenomenon involving urine from females in oestrus has also been demonstrated for wild stocks of mice (Mus musculus) maintained in the laboratory (Drickamer, 1984a).

The 9 experiments reported here were designed to extend existing knowledge of the chemosignal in the urine of oestrous females.

\section{General Methods}

The mice used for these experiments were from a randomly bred closed colony of ICR/Alb house mice (Mus musculus). All colony and test mice were housed in shoe-box cages of polypropylene 
measuring $15 \times 28 \times 15 \mathrm{~cm}$ deep with opaque sides and fitted wire lids. Bedding of ground wood shavings was changed once each week. Purina Mouse Chow and water were supplied ad libitum throughout each experiment. All of the breeding, urine collection and experimental testing were conducted in a suite of four rooms maintained at $21-25^{\circ} \mathrm{C}$ and $30-60 \%$ relative humidity on a $12 \mathrm{~h}$ light: $12 \mathrm{~h}$ dark daily regimen with lights on from $06: 00$ to 18:00 h. Previous investigations (Drickamer, 1974a, b) involving several treatments with different chemosignals were conducted simultaneously in the same and adjoining rooms with no danger of stimulus interference between cages.

Pregnant female mice were isolated in individual cages during the last week before parturition. All cages were then checked daily and births were recorded. On the day of birth each litter was counted and all young were sexed. Each litter was reduced to exactly 10 young, at least 3 of which were males. Litters of fewer than 10 young were discarded. Mice were weaned 21 days after birth and were immediately assigned to a treatment group and cage according to a random sequence.

Each mouse was examined daily from Day 21 until the occurrence of vaginal introitus. Starting at vaginal introitus a vaginal lavage was made each day until the occurrence of first vaginal oestrus. The daily wet-mount vaginal smears were examined immediately with a light microscope and the cellular contents were judged to determine the stage of the oestrous cycle according to the criteria of Rugh (1968) and Vandenbergh (1969).

For each experiment a group of 40-120 individually caged adult females was maintained as urine donors. A daily vaginal smear was taken from each mouse in this group and urine was collected only from those females that had $90 \%$ or more cornification of the smear as a criterion for oestrus. Since the vaginal cornification is brought about, in part, by the action of oestrogen, it is safe to assume that the mouse was in oestrus several hours before the time that the cornified smear was obtained. Urine was collected by holding the mouse over a Petri dish and gently squeezing the flanks. In this manner fresh urine was collected each day from 4-8 females. Treatments were applied to the external nares of the test subjects by using 3-4 strokes of a small paintbrush. Each test female was monitored daily as described above until the occurrence of first vaginal oestrus. Values are given as mean \pm 1 s.e.m.

\section{Detailed Methods and Results}

\section{Experiments $I a$ and $I b$}

Methods. These experiments were designed to test the age and duration of treatment with urine from oestrous females affecting the age of puberty in young female mice. For Exp. Ia, 90 female mice were weaned at 21 days of age and assigned to one of 6 treatments ( 15 mice/treatment), each involving an individually caged mouse painted daily on the external nares with (1) water, as a control procedure, or urine from singly-caged oestrous females, (2) on Day 21 only, (3) on Day 23 only, (4) on Day 25 only, (5) on Day 27 only, or (6) on Day 29 only.

For Exp. Ib the procedures and sample sizes were identical to those of Exp. Ia except that there were only 5 treatment conditions: (1) water, or urine from females in oestrus painted daily on the external nares (2) for Days 21-23, (3) for Days 24-26, (4) for Days 27-29, or (5) for Days 30-32. Each test mouse was monitored until the occurrence of first vaginal oestrus.

Results. Analysis of variance for the results from Exp. Ia revealed no statistically significant differences in the mean ages for first oestrus across the 6 treatments (Table 1). An analysis of variance of the results for Exp. Ib $(\mathrm{F}=6.519$; d.f. $=4 ; P<0.005)$ and post-hoc comparisons $(P<0.02)$ indicated that young females treated on Days 30-32 with urine from oestrous females $(33 \cdot 1 \pm 0.9$ days) or with water (control; $34.3 \pm 1 \cdot 3$ days) reached puberty significantly later than did mice treated on Days 21-23 (29.9 \pm 0.8 days), Days 24-26 (30.1 \pm 0.7 days), or Days 27-29 (30.5 $\pm 1 \cdot 0$ days). There were no differences in the degree of puberty acceleration produced in the last three treatment conditions. 
Table 1. Mean age $( \pm 1$ s.e.m., 15 mice/treatment) for first vaginal oestrus in female mice treated with urine from adult females in oestrus for 1 day only at the specified age

\begin{tabular}{lc}
\hline Treatment & $\begin{array}{c}\text { Age of first oestrus } \\
\text { (days) }\end{array}$ \\
\hline Water (control) & $34 \cdot 1 \pm 1 \cdot 1$ \\
Treated on Day 21 only & $33 \cdot 6 \pm 1 \cdot 0$ \\
Treated on Day 23 only & $33 \cdot 3 \pm 0 \cdot 9$ \\
Treated on Day 25 only & $35 \cdot 1 \pm 0 \cdot 6$ \\
Treated on Day 27 only & $34 \cdot 5 \pm 1 \cdot 0$ \\
Treated on Day 29 only & $36 \cdot 1 \pm 1 \cdot 1$ \\
\hline $\mathrm{F}=1 \cdot 107 ;$ d.f. $=5,84 ; P=$ n.s. &
\end{tabular}

\section{Experiment $I I$}

Methods. This experiment was conducted to assess the duration of daily exposure to the urinary chemosignal from oestrous females necessary to produce acceleration of puberty in young females. There were 6 treatment conditions ( 15 mice/treatment). Mice were either maintained in their home cage throughout (1) as a control, or moved to a cage containing the urine of oestrous females for (2) $10 \mathrm{~min} /$ day, (3) $30 \mathrm{~min} /$ day, (4) $1 \mathrm{~h} /$ day, (5) $2 \mathrm{~h} /$ day, or (6) $4 \mathrm{~h} / \mathrm{day}$. The control procedure for moving the test females between cages has no effect on puberty (Drickamer, 1982a). To provide cages with bedding containing the urine from females in oestrus the following procedure was used. Pooled urine from oestrous females was distributed to 75 standard cages that each had $100 \mathrm{ml}$ of clean bedding spread evenly on the cage bottom. Five drops, $0.02 \mathrm{ml}$ each (total of $0.1 \mathrm{ml}$ ), of urine were placed on the bedding in each cage with a Hamilton syringe. One drop was placed in each corner and one in the centre of the bottom of the cage. Upon completion of this procedure the 75 cages were randomly arranged into 5 groups of 15 cages each. The test females were then introduced, one per soiled cage, and maintained in these cages for the prescribed period. Each mouse was then returned to its home cage. At the end of the day the urine exposure cages were emptied and cleaned and a fresh set of 75 cages was prepared for the next day. Treatment continued for each mouse for 10 days, or until the occurrence of first vaginal oestrus. Each test mouse was monitored daily as described in the 'General Methods'.

Results. Test females exposed to water or to the urine of oestrous females for $10 \mathrm{~min}, 30 \mathrm{~min}$ or $1 \mathrm{~h} /$ day did not differ in the age of puberty (Table 2). Females exposed to the oestrous urine for 2 or $4 \mathrm{~h} /$ day had an accelerated age of puberty. There was no difference in the age of sexual maturation for females exposed for 1 or $2 \mathrm{~h} /$ day.

\section{Experiment III}

Methods. The third experiment involved a test of whether there was any daily pattern of release or effectiveness of the substance from oestrous females that accelerates female puberty, or whether there was any daily pattern in terms of the sensitivity of the young females to the urine of oestrous females.

A cross-classified design like those employed previously to test the urine of adult males and grouped females (Drickamer, 1982b) was used. Several weeks before the start of the experiment urine was collected from oestrous females at 00:00, 06:00, 12:00 or 18:00 h and treatments were applied to young females at 00:00,06:00,12:00 or 18:00 h. There were 12 test females for each of the 16 cells of the $4 \times 4$ design. During the urine collection process, samples of $1 \mathrm{ml}$ urine for each designated hour were frozen at $-70^{\circ} \mathrm{C}$ (freezing does not affect the effectiveness of the chemosignal). During the experimental phase the vials containing the urine were removed from the freezer, 
Table 2. Mean age ( \pm 1 s.e.m., 15 mice/treatment) for first vaginal oestrus in female mice exposed to the urine of adult females in oestrus for different durations each day

\begin{tabular}{ll}
\hline Treatment & $\begin{array}{c}\text { Age of first oestrus } \\
\text { (days) }\end{array}$ \\
\hline Water (control) & $36 \cdot 7 \pm 1 \cdot 1^{\mathrm{c}}$ \\
Exposed for $10 \mathrm{~min} /$ day & $35 \cdot 4 \pm 1 \cdot 0^{\mathrm{c}}$ \\
Exposed for $30 \mathrm{~min} /$ day & $35 \cdot 7 \pm 0 \cdot 9^{\mathrm{c}}$ \\
Exposed for $1 \mathrm{~h} /$ day & $33 \cdot 6 \pm 0 \cdot 8^{\mathrm{b}, \mathrm{c}}$ \\
Exposed for $2 \mathrm{~h} /$ day & $30 \cdot 8 \pm 0 \cdot 7^{\mathrm{a}, \mathrm{b}}$ \\
Exposed for $4 \mathrm{~h} /$ day & $30 \cdot 4 \pm 0 \cdot 7^{\mathrm{a}}$ \\
\hline $\mathrm{F}=8 \cdot 544$; d.f. $=5,83 ; P<0 \cdot 001$. \\
Those means not marked with the same superscript letter \\
are significantly different at $P<0.02$ by Duncan's \\
New Multiple Range Test.
\end{tabular}

Table 3. Mean ages in days ( \pm 1 s.e.m., 12 mice/treatment combination) for first vaginal oestrus in female mice treated at one of four different times of the day with urine from adult females in oestrus that was collected at one of four different times of the day (a) and the analysis of variance (b)

\begin{tabular}{ccccc}
\hline & \multicolumn{4}{c}{ Time of collection } \\
\cline { 2 - 5 } $\begin{array}{c}\text { Time of } \\
\text { treatment (h) }\end{array}$ & $00: 00 \mathrm{~h}$ & $06: 00 \mathrm{~h}$ & $12: 00 \mathrm{~h}$ & $18: 00 \mathrm{~h}$ \\
\hline $00: 00$ & $30 \cdot 4 \pm 0 \cdot 8$ & $30 \cdot 0 \pm 0 \cdot 6$ & $35 \cdot 2 \pm 1 \cdot 1$ & $35 \cdot 6 \pm 1 \cdot 2$ \\
$06: 00$ & $29 \cdot 7 \pm 0.8$ & $30 \cdot 4 \pm 0 \cdot 7$ & $35 \cdot 8 \pm 1 \cdot 1$ & $35 \cdot 1 \pm 1 \cdot 2$ \\
$12: 00$ & $31 \cdot 2 \pm 0 \cdot 7$ & $30 \cdot 2 \pm 0 \cdot 7$ & $35 \cdot 4 \pm 1 \cdot 4$ & $32 \cdot 4 \pm 1 \cdot 2$ \\
$18: 00$ & $30 \cdot 5 \pm 0 \cdot 8$ & $30 \cdot 1 \pm 1 \cdot 0$ & $33 \cdot 0 \pm 1 \cdot 3$ & $33 \cdot 5 \pm 0.8$ \\
\hline
\end{tabular}

(b) Analysis of variance:

\begin{tabular}{lrccc}
\hline Factor & d.f. & Mean square & F-ratio & Significance \\
\hline Time of collection & 3 & 283.63 & 24.292 & $P<0.001$ \\
Time of treatment & 3 & $10 \cdot 64$ & 0.912 & n.s. \\
Collection $\times$ treatment & 9 & 12.93 & 1.108 & n.s. \\
Error & 176 & 11.68 & & \\
Total & 191 & & & \\
\hline
\end{tabular}

Post-hoc comparison for Time of Collection (Duncan's New Multiple Range Test) with those means not marked by the same superscript letter significantly different at $P<0.02$ :

Time of urine

$\begin{array}{lcccc}\text { collection } & 00: 00 \mathrm{~h} & 06: 00 \mathrm{~h} & 12: 00 \mathrm{~h} & 18: 00 \mathrm{~h} \\ \text { Mean } \pm 1 \text { s.e.m. } & 30 \cdot 5 \pm 0 \cdot 5^{\mathrm{a}} & 30 \cdot 2 \pm 0 \cdot 5^{\mathrm{a}} & 34 \cdot 8 \pm 0 \cdot 8^{\mathrm{b}} & 34 \cdot 1 \pm 0 \cdot 7^{\mathrm{b}}\end{array}$

thawed to room temperature and used to treat young females. Vials were discarded immediately after use. Using this procedure each test female was treated at the appropriate time each day and with urine from the designated collection period for 10 days or until the occurrence of first oestrus. Each test female was monitored daily as described in 'General Methods'.

Results. The individual and group means and the post hoc comparisons of the means are presented in Table 3(a) and the analysis of variance in Table 3(b). Only the main treatment effect for time of urine collection was statistically significant: urine collected at 00:00 or $06: 00 \mathrm{~h}$ resulted in significantly earlier onset of first oestrus in test females than did urine collected at 12:00 or 18:00 $\mathrm{h}$. Neither the main treatment factor for time of urine application to test females nor the interaction term were significant. 


\section{Experiment $I V$}

Methods. This experiment involved a year-long compilation of data to assess whether there was any seasonal pattern for the acceleration of puberty due to exposure to urine from females in oestrus. During each of the 12 months of the year 14 females were treated with water and 14 other test females were treated with urine collected from individually caged females in oestrus. Each female subject was monitored daily until the occurrence of first vaginal oestrus. Urine collection and treatment procedures were the same as those described in 'General Methods'.

Results. Separate $t$ tests were conducted for each month to compare the results for control and urine-treated females. Significant acceleration of puberty occurred in the months from April to September inclusive, but no differences were detected between the control and treated females for the months from October to March inclusive (Table 4).

Table 4. Mean ages in days ( \pm 1 s.e.m., 14 mice/treatment) for first vaginal oestrus in female mice treated with water or with urine from females in oestrus during each month of the year

\begin{tabular}{lcccc}
\hline Month & Water & Urine & $t($ d.f. $=26)$ & Significance \\
\hline January & $33.4 \pm 0.7$ & $34.8 \pm 0.9$ & 1.201 & n.s. \\
February & $34.4 \pm 0.9$ & $34.4 \pm 0.7$ & 0.062 & n.s. \\
March & $33.1 \pm 0.8$ & $34.9 \pm 1.0$ & 1.197 & n.s. \\
April & $35.1 \pm 0.8$ & $30.6 \pm 0.8$ & 3.971 & $P<0.001$ \\
May & $35.1 \pm 0.8$ & $30.7 \pm 0.8$ & 4.137 & $P<0.001$ \\
June & $35.5 \pm 0.9$ & $30.1 \pm 0.7$ & 5.001 & $P<0.001$ \\
July & $35.4 \pm 0.9$ & $29.6 \pm 0.8$ & 4.654 & $P<0.001$ \\
August & $34.9 \pm 0.9$ & $29.7 \pm 0.8$ & 4.364 & $P<0.001$ \\
September & $35.2 \pm 0.8$ & $30.3 \pm 0.5$ & 5.173 & $P<0.001$ \\
October & $34.5 \pm 1.0$ & $32.9 \pm 0.8$ & 1.226 & n.s. \\
November & $33.9 \pm 0.8$ & $34.1 \pm 1.0$ & 0.236 & n.s. \\
December & $33.1 \pm 0.7$ & $34.8 \pm 0.8$ & 1.591 & n.s. \\
\hline
\end{tabular}

\section{Experiment $V$}

Methods. This experiment tested whether the puberty-accelerating chemosignal found in the excreted urine of oestrous females is also present in the bladder urine of oestrous females. Bladder urine from female mice in dioestrus delays the onset of puberty in test females (McIntosh \& Drickamer, 1977).

Females were weaned at 21 days of age and assigned to 1 of 3 treatments ( 12 mice/treatment). Individually caged test females were treated daily on the external nares with (1) water (control), (2) excreted urine from females in oestrus, or (3) bladder urine from females in oestrus. Excreted urine was collected from 4-6 oestrous females each day. Another 2-4 oestrous females were killed with ether each day, the abdominal cavity was opened immediately and the urine was removed from the bladder with a hypodermic syringe. Each test female was treated and monitored daily as described in 'General Methods'.

Results. Both treatment with excreted (29.9 \pm 0.9 days) and bladder $(29.7 \pm 1.0$ days $)$ urine resulted in mean ages for first oestrus that were significantly earlier $(\mathrm{F}=7 \cdot 444$; d.f. $=2,31$; $P<0.005)$ than the mean age for the control treatment $(34.7 \pm 1.2$ days $)$.

\section{Experiment VI}

Methods. This experiment was designed to assess the daily amount of urine from females in oestrus needed to produce the acceleration of puberty. 
Female mice were weaned at 21 days of age and assigned to 1 of 5 treatments $(12 \mathrm{mice} /$ treatment), each involving individually caged female mice treated daily on the external nares with (1) water (control), or (2) $0.1 \mathrm{ml},(3) 0.01 \mathrm{ml}$, (4) $0.001 \mathrm{ml}$, or (5) $0.0001 \mathrm{ml}$ of urine from females in oestrus. Test females were treated by using a Hamilton syringe to deliver exact amounts in very small quantities. For treatment (2) full strength urine was used. Serial dilution using distilled water (Drickamer, 1984b) was used to obtain the smaller dose levels for treatments (3), (4) and (5); these were applied in $0 \cdot 1 \mathrm{ml}$ each day. Urine treatment continued until the occurrence of first oestrus. Each test female was monitored daily as described in 'General Methods' until the occurrence of first vaginal oestrus.

Results. Daily doses of 0.1 (30.1 \pm 0.9 days), 0.01 (29.8 \pm 0.8 days), and $0.001 \mathrm{ml}$ urine/day $(31.2 \pm 0.9$ days) were sufficient to produce acceleration of puberty relative to the water-treated control mice $(\mathrm{F}=8.762$; d.f. $=4,55 ; P<0.001)$. However, the daily dosage of $0.0001 \mathrm{ml}$ urine/day $(34 \cdot 3 \pm 0.7$ days) was not sufficient to produce a mean age at puberty significantly different from that of control mice $(35 \cdot 2 \pm 1 \cdot 0$ days).

\section{Experiment VII}

Methods. Investigations of the other puberty-influencing chemosignals in mice have provided evidence that some of the signals may be of low volatility and received by the vomeronasal system, whereas others may be more volatile and received by the olfactory epithelium (Keverne, 1979; Drickamer \& Assmann, 1981; Lomas \& Keverne, 1982). This experiment was designed to determine the relative volatility of the substance in urine from oestrous females that accelerates puberty in young female mice.

Females were weaned at 21 days of age and assigned to 1 of 6 treatments ( 16 mice/treatment), each involving individually caged subjects treated (1) by painting water daily on the external nares (control), (2) by painting $0.02 \mathrm{ml}$ urine from oestrous females daily on the external nares, (3) by providing the mouse with a daily sample of $50 \mathrm{ml}$ of bedding soiled by placing $0.1 \mathrm{ml}$ urine from oestrous females on clean bedding before adding it to the cage containing the test subject, (4) putting $0.02 \mathrm{ml}$ urine from females in oestrus directly on the external nares with a Hamilton syringe, (5) by placing $0.02 \mathrm{ml}$ urine from oestrous females daily on a piece of cotton contained within a perforated plastic capsule (Drickamer \& Hoover, 1979), or (6) allowing $0.02 \mathrm{ml}$ urine from oestrous females to dry in air on a $5 \mathrm{~cm} \times 10 \mathrm{~cm}$ glass slide and then placing the slide in the cage with the test female. For treatment (3), $150 \mathrm{ml}$ of bedding were removed from the cage every 3rd day to prevent the accumulation of bedding. For treatment (6), the glass slide from the previous day was removed before placing a freshly prepared slide in the cage.

Table 5. Mean ages ( \pm 1 s.e.m., 16 mice/treatment) for first vaginal oestrus in female mice given different forms of daily exposure to urine from females in oestrus

\begin{tabular}{lc}
\hline Treatment & $\begin{array}{c}\text { Age of } \\
\text { first oestrus } \\
\text { (days) }\end{array}$ \\
\hline Water (control) & $35 \cdot 4 \pm 0 \cdot 9^{\mathrm{c}}$ \\
$0 \cdot 05 \mathrm{ml} /$ day painted on external nares & $29 \cdot 8 \pm 0 \cdot 4^{\mathrm{a}}$ \\
Daily sample of soiled bedding & $32 \cdot 6 \pm 0 \cdot 7^{\mathrm{b} . \mathrm{c}}$ \\
$0 \cdot 02 \mathrm{ml} /$ day delivered by syringe & $29 \cdot 4 \pm 0 \cdot 6^{\mathrm{a}}$ \\
$0 \cdot 05 \mathrm{ml} /$ day injected into perforated capsule & $35 \cdot 2 \pm 0 \cdot 9^{\mathrm{c}}$ \\
$0 \cdot 1 \mathrm{~m} /$ day dried onto glass plate & $34 \cdot 7 \pm 0 \cdot 8^{\mathrm{c}}$ \\
\hline $\mathrm{F}=13 \cdot 675 ;$ d.f. $=5,87 ; P<0 \cdot 001$. & \\
Those means not marked with the same superscript letter are significantly different at \\
$P<0.02$ by Duncan's New Multiple Range Test.
\end{tabular}


Results. Mice treated directly on the nares with the urine, by painting or with the syringe, attained first oestrus significantly earlier than did mice treated with water or provided with urine in a capsule or on a glass plate (Table 5). Test subjects given daily samples of soiled bedding were intermediate in the mean age of puberty.

\section{Experiment VIII}

Methods. Young female mice treated simultaneously with urinary chemosignals from 2 or 3 sources attain puberty significantly later than do control females treated with water when one of the sources used for treatment consists of grouped females (Drickamer, 1982c). In this experiment, the effects of simultaneous treatment of young female mice with urine from two sources, with one of the sources being oestrous females, were tested.

Female mice were weaned at 21 days of age and assigned to 1 of 8 treatments $(15$ mice/treatment) each involving individually caged female mice treated daily on the external nares with (1) water (control), (2) urine from females in oestrus, (3) urine from adult males, (4) urine from adult females housed $8 /$ cage, (5) urine from pregnant or lactating females, (6) urine from females in oestrus plus urine from males, (7) urine from females in oestrus plus urine from pregnant or lactating females, or (8) urine from females in oestrus plus urine from adult females housed $8 /$ cage. All treatments involved urine collected fresh daily using the methods described for Exp. I. Urine treatments involved $0.02 \mathrm{ml}$ per day for each mouse; all of this volume was of one type of urine or consisted of $0.01 \mathrm{ml}$ of each of two urine types. All urine applications were made using Hamilton syringes. Separate syringes were used for each different urine source. All test females were monitored until the occurrence of first vaginal oestrus as described in 'General Methods'.

Results. Mice treated with urine from oestrous females only, males only, pregnant or lactating females only, or paired combinations of these, including urine from oestrous females, were accelerated in the attainment of puberty relative to control females (Table 6). In contrast, test mice treated only with urine from grouped females or urine from females in oestrus plus urine from grouped females were delayed in the age of puberty relative to the control mice (Table 6).

Table 6. Mean ages ( \pm 1 s.e.m., 15 mice/treatment) for first vaginal oestrus in female mice given daily urine treatments involving a single type of urine source or two urine sources used simultaneously in equal proportions

Treatment

Age of

first oestrus

(days)

Water (control)

Urine from females in oestrus

Urine from adult males

Urine from grouped adult females (8/cage)

Urine from pregnant or lactating females

Urine from females in oestrus and urine from males

Urine from females in oestrus and urine from grouped females (8/cage)

Urine from females in oestrus and urine from pregnant or lactating females
$34 \cdot 7 \pm 0.8^{b}$

$29 \cdot 1 \pm 0.6^{\mathrm{a}}$

$28 \cdot 8 \pm 0 \cdot 7^{\mathrm{a}}$

$39.8 \pm 0.7^{\mathrm{c}}$

$29 \cdot 9 \pm 0.9^{\mathrm{a}}$

$29 \cdot 4 \pm 0.6^{\mathrm{a}}$

$38 \cdot 5 \pm 0 \cdot 7^{\mathrm{c}}$

$30 \cdot 3 \pm 0 \cdot 8^{a}$

$\mathrm{F}=37.500 ;$ d.f. $=7,100 ; P<0.001$.

Those means not marked with the same superscript letter are significantly different at $P<0.02$ by Duncan's New Multiple Range Test.

\section{Experiment $I X$}

Methods. The urinary chemosignals from males and group-caged females that accelerate and delay puberty respectively in young test female mice are influenced both by food deprivation and shortened daylength (Drickamer, 1984b). The final experiment tested whether altering daylength 
or subjecting the donor females to food deprivation would change the release of the pubertyaccelerating chemosignal in the urine of oestrous females.

Females were weaned at 21 days of age and assigned to 1 of 4 treatments ( 15 mice/treatment), each involving individually caged females painted daily on the external nares with (1) water (control), or urine from females in oestrus (2) housed under 'normal' conditions involving $12 \mathrm{~h}$ light and $12 \mathrm{~h}$ dark (12L:12D) each day and food available ad libitum (3) housed under conditions involving the 12L:12D lighting regimen, but with all food removed every other day, or (4) housed with adlibitum food, but in a $6 \mathrm{~L}: 18 \mathrm{D}$ regimen. Three separate groups of 20 individually caged adult female mice were utilized as urine donors for the treatments (2)-(4). Mice in the food-restricted condition were maintained on that regimen for 1 week before urine collection; they were maintained on the restricted schedule for an additional 2-week period during which they were used for urine collection. These mice weighed $94-103 \%$ of their initial body weights at the conclusion of the 2-week period during which they were used for urine collection. Mice housed under conditions involving $6 \mathrm{~L}: 18 \mathrm{D}$ were maintained in that regimen for 3 weeks before and during the 2 weeks when they were used for urine collection. Each test female was monitored until the occurrence of first vaginal oestrus as described in 'General Methods'.

Results. All three of the treatments involving urine from oestrous females (12L:12D and adlibitum food, $28.4 \pm 0.6$ days; $12 \mathrm{~L}: 12 \mathrm{D}$ and restricted food, $30.6 \pm 1 \cdot 1$ days; $6 \mathrm{~L}: 18 \mathrm{D}$ and ad-libitum food, $30.4 \pm 0.8$ days) resulted in significantly earlier mean ages $(F=7.333$; d.f. $=3,56$; $P<0.001)$ for first oestrus than did the control treatment ( $34.8 \pm 0.9$ days).

\section{Discussion}

Two types of conclusions can be drawn from these experiments, those that pertain to the specifics of the effects of urine from female mice in oestrus on the age of puberty in conspecific females, and those that involve comparisons of this chemosignal with the other three known urinary chemosignals that influence the age of sexual maturation in female mice.

The results of the experiments support the conclusions that the substance in the urine of oestrous females that accelerates female sexual development is effective in very small doses, is found both in bladder as well as excreted urine, and is relatively non-volatile. Release of the substance is not affected by shortened photoperiod or food deprivation regimens for the donors. Also, at least 2 and probably 3 days of chemosignal stimulation are needed before about 28 or 29 days of age for acceleration to occur and the mice must be exposed to the chemosignal for at least $2 \mathrm{~h} /$ day to obtain full acceleration. The chemosignal in the urine of oestrous females is affected by daily rhythms and by seasonal factors. Lastly, the effectiveness of this chemosignal can be blocked by simultaneous treatment of the young females with urine from adult grouped female mice- delays in puberty occur under this treatment regimen. There is no enhancement of the acceleratory effect when the test mouse is treated simultaneously with urine from females in oestrus and either of the other two known acceleratory substances from males, and pregnant or lactating females.

Several of these conclusions are self-explanatory with regard to the results from the individual experiments, others require brief explanations. The substance in the urine of female mice in oestrus that accelerates puberty in conspecific females is relatively non-volatile. The acceleratory effect works when young mice have direct contact with the urine containing the chemosignal substance, but the effectiveness of the substance is lost when the test mouse cannot make direct contact with the urine. With regard to daily rhythms it appears that this chemosignal is most effective when collected at the middle of and near the end of the dark portion of the $12 \mathrm{~L}: 12 \mathrm{D}$ cycle. These results make sense if we consider that the female donors were in oestrus during the period from 00:00 to $06: 00 \mathrm{~h}$ and their urine was collected within the same time frame as the ovulatory hormonal changes. The substances that enter the urine during the period around the time of oestrus must be metabolized or removed from the urine before the urine collection at 12:00 $\mathrm{h}$. Treatments applied to 
young females were equally effective regardless of when during the daily cycle they were made. Lastly, the chemosignal was effective in producing significant acceleration of puberty only during the months from April to September inclusive and not at other times of the year. This seasonal pattern may be due to changes in the nature of the chemosignal substance during the year, or to seasonal changes in the sensitivity of the young females to the substance.

A variety of interesting comparisons and contrasts can be drawn between the present results for the substance in the urine of oestrous females that accelerates sexual maturation in female mice and the previously known information regarding the other three urinary chemosignals that have been reported that affect the timing of sexual development.

The signal from oestrous females is similar to the other two acceleratory signals, those from males and pregnant or lactating females, in that it is effective when treatment occurs for only 3 days, so long as that treatment starts before about Days 28 or 29 of age (Colby \& Vandenbergh, 1974; Drickamer, 1984c). The oestrous urine signal is similar to the other two acceleratory substances in that its effectiveness is blocked, and, in fact, delays in puberty result, when the oestrous urine signal is applied to test females at the same time as the urine of grouped females (Drickamer, 1982c). However, all experiments to date involving simultaneous treatment with urine from several sources have been conducted with equal proportions of the two signals; work is now in progress using various combinations of urinary chemosignals in unequal proportions to treat young females.

Like all of the other chemosignals, the effectiveness of the substance in the urine of females in oestrus is influenced by the seasons (Drickamer, 1984e); current research indicates that the observed seasonal rhythms are due exclusively to changes in sensitivity on the part of the young females (L. C. Drickamer, unpublished). This hypothesis has not been tested in young females with regard to urine from females in oestrus, but, based on the findings with the other three urinary chemosignals that influence puberty, I strongly suspect that the same would be true for this substance. All 4 of the chemosignals that affect puberty appear to be effective in very small doses (Drickamer, 1984d). Certainly, these substances are likely to be present in the natural environments of the house mouse in sufficient quantities to produce the observed priming effects on reproductive physiology. The substance in the urine of oestrous females is also similar to the other three chemosignals in that it is found in bladder as well as excreted urine (McIntosh \& Drickamer, 1977; Drickamer \& Murphy, 1978). Lastly, all 4 substances appear to require minimum daily exposures of $1-2 \mathrm{~h}$ to be effective (Drickamer, 1983a, b).

There are some critical differences between the 4 chemosignal substances. First, there are differences in volatility; it appears that the male urinary substance and the signal in the urine of females in oestrus are quite non-volatile (Kaneko, Debski, Wilson \& Whitten, 1980; Drickamer \& Assmann, 1981). The puberty-delaying signal in the urine of grouped female mice is relatively non-volatile, although there have been some contradictory results in this regard (Keverne, 1979; Drickamer \& Assmann, 1981; Lomas \& Keverne, 1982). The urinary signal from pregnant or lactating females is much more volatile than the other 3 substances (Drickamer \& Hoover, 1979).

Second, the urinary signal from females in oestrus is not influenced by food deprivation or shortened photoperiod; the substances in the urine of males and grouped females are affected by one or both of these environmental factors (Drickamer, 1984b). It might be that, on average, a female is in oestrus on fewer days over a delimited time period under the altered environmental conditions, but when she is in oestrus her urine does, in fact, contain the puberty-accelerating chemosignal. This finding suggests that the substance from oestrous females is rather closely dependent upon the hormones and/or releasing factors present in the donor mouse near the time of oestrus and ovulation.

Third, the daily variations in release of the urinary substances by donor mice and sensitivity on the part of young recipient females are different for each chemosignal. No clear links have yet been postulated between internal hormonal and physiological events in the mice and the daily patterns of chemosignal release (Drickamer, 1982b, 1984f). For the signal in the urine of oestrous females 
it is possible that the timing of release coincides with the period of oestrus which generally occurs during the dark phase of the daily cycle. No sound explanations have yet been found for the daily patterns of sensitivity in young females to some of the signals, although there were no variations in this regard with respect to the substance in the urine of females in oestrus.

This research was supported by United States Public Health Service Grant Award No. HD-08585.

\section{References}

Colby, D.R. \& Vandenbergh, J.G. (1974) Regulatory effects of urinary pheromones on puberty in the mouse. Biol. Reprod. 11, 268-279.

Drickamer, L.C. (1974a) Sexual maturation of female mice: social inhibition. Devl Psychobiol. 7, 257-265.

Drickamer, L.C. (1974b) Contact stimulation, androgenized females and accelerated sexual maturation in female mice. Behav. Biol. 12, 101-110.

Drickamer, L.C. (1982a) Delay and acceleration of puberty in female mice by urinary chemosignals from other females. Devl Psychobiol. 15, 433-442.

Drickamer, L.C. (1982b) Acceleration and delay of sexual maturation in female mice via urinary chemosignals: circadian rhythm effects. Biol. Reprod. 27, 596-601.

Drickamer, L.C. (1982c) Acceleration and delay of first vaginal oestrus in female mice by urinary chemosignals: dose levels and mixing urine treatment sources. Anim. Behav. 30, 456-460.

Drickamer, L.C. (1983a) Male acceleration of puberty in female mice (Mus musculus). J. comp. Psychol. 97, 191-200.

Drickamer, L.C. (1983b) Chemosignal effects on puberty in young female mice: urine from pregnant and lactating females. Devl Psychobiol. 16, 207-217.

Drickamer, L.C. (1984a) Urinary chemosignals from mice (Mus musculus): acceleration and delay of puberty in related and unrelated young females. $J$. comp. Psychol. 89, 414-420.

Drickamer, L.C. (1984b) Urinary chemosignals and puberty in female house mice: effects of photoperiod and food deprivation. Physiol. Behav. 33, 907-911.

Drickamer, L.C. (1984c) Acceleration of puberty in female mice by a urinary chemosignal from pregnant or lactating females: timing and duration of stimulation. Devl Psychobiol. 17, 451-456.

Drickamer, L.C. (1984d) Effects of very small doses of urine on acceleration and delay of sexual maturation in female house mice. J. Reprod. Fert. 71, 475-477.

Drickamer, L.C. (1984e) Seasonal variation in acceleration and delay of sexual maturation in female mice by urinary chemosignals. J. Reprod. Fert. 72, 55-58.

Drickamer, L.C. (1984f) Acceleration of puberty in female mice by a chemosignal from pregnant and lactating females: circadian rhythm effects. Biol. Reprod. 31, 104-108.

Drickamer, L.C. (1985) Delay of sexual maturation in female mice by a urinary chemosignal: dominance effects among donor females. J. comp. Psychol. 99, 411-419.
Drickamer, L.C. (1986) Puberty-influencing chemosignals in house mice: ecological and evolutionary considerations. In Chemical Signals in Vertebrates, Vol. IV. Eds D. Duvall, D. Muller-Schwarze and R. M. Silverstein. Plenum Press, New York, in press.

Drickamer, L.C. \& Assmann, S. (1981) Acceleration and delay of puberty in female house mice: methods of delivery of the urinary stimulus. Devl Psychobiol. 14, 487-497.

Drickamer, L.C. \& Hoover, J.E. (1979) Effects of urine from pregnant and lactating female house mice on sexual maturation of juvenile females. Devl Psychobiol. 12, 545-551.

Drickamer, L.C. \& Murphy, R.X. (1978) Female mouse maturation: effects of excreted and bladder urine from juvenile and adult males. Devl Psychobiol. 11, 63-72.

Kaneko, N., Debski, E.A., Wilson, M.C. \& Whitten, W.K. (1980) Puberty acceleration in mice. 2. Evidence that the vomero-nasal organ is a receptor for the primer pheromone in male mouse urine. Biol. Reprod. 22, 873-878.

Keverne, E.B. (1979) The dual olfactory projections and their significance for behavior. In Chemical Ecology: Odour Communication in Animals, pp. 75-83. Ed. F. J. Ritter. Elsevier, Amsterdam.

Lomas, D.E. \& Keverne, E.B. (1982) Role of the vomeronasal organ and prolactin in the acceleration of puberty in female mice. J. Reprod. Fert. 66, 101-107.

McIntosh, T.K. \& Drickamer, L.C. (1977) Excreted urine, bladder urine and the delay of sexual maturation in female house mice. Anim. Behav. 9, 370-378.

Rugh, R. (1968) The Mouse: its Reproduction and Development. Burgess, Minneapolis.

Vandenbergh, J.G. (1969) Male odor accelerates female sexual maturation in mice. Endocrinology 84, 658-660.

Vandenbergh, J.G. (1983) Social factors controlling puberty in the female mouse. In Hormones and Behavior in Higher Vertebrates, pp. 262-274. Eds J. Balthazart, E. Prove \& R. Gilles. Springer-Verlag, Berlin.

Vandenbergh, J.G., Drickamer, L.C. \& Colby, D.R. (1972) Social and dietary factors in the sexual maturation of female mice. J. Reprod. Fert. 28, 397-405.

Received 30 November 1985 